\title{
Critical Appraisal of Published Qualitative Research Papers in the Field of Nursing Management by Iranian authors: A cross-sectional Study
}

\author{
Abbas Heydari ${ }^{1}$, Seyed Majid Vafaei ${ }^{2}$, Mahmoud Bakhshi ${ }^{3}$ \\ ${ }^{1}$ Evidence-Based Caring Research Center, Department of Medical-Surgical Nursing, School of Nursing and Midwifery, \\ Mashhad University of Medical Sciences,Mashhad, Iran \\ ${ }^{2} P h D$ candidate in Nursing, School of Nursing and Midwifery, Mashhad University of Medical Sciences, Mashhad, Iran \\ ${ }^{3}$ Evidence-Based Care Research Center, Department of Operating Room and Anesthesia, School of Nursing and \\ Midwifery, Mashhad University of Medical Sciences, Mashhad, Iran
}

\begin{abstract}
SUMMARY
The growing number of doctoral graduates in nursing management, together with more focus on qualitative studies, has contributed to the development of qualitative studies. This study aimed to provide a critical appraisal of qualitative research papers in the field of nursing management by Iranian authors, published in national and international journals.

In a cross-sectional study, international and Persian electronic databases were used for a systematic search of the relevant literature using the keywords: qualitative studies, nursing management, and Iran. Criteria provided by the Critical Appraisal Skills Program (CASP) for the qualitative studies checklist was used for quality appraisal of the included studies.

Of the 22 qualitative studies appraised, $48 \%$ had used grounded theory and $22 \%$ had adopted the research method of content analysis. The mean score for ethical consideration was 1.66 out of 4 . The mean scores for rigor and research credibility were 5.123 out of 9 and 1.66 out of 4, respectively. In terms of research purpose and methodology, mean scores were 3.33 out of 4 and 2.22 out of 3, respectively. Quality of research design obtained the mean score of 2.66 out of 6 and the score for method of data collection was 4.44 out of 7 .

Results showed that quality of the published qualitative studies in the field of nursing management by Iranian authors seemed not appropriate and the most significant weakness was related to the partial compliance with ethical principles.
\end{abstract}

Key words: critical appraisal, qualitative research papers, nursing management, Iran 


\section{INTRODUCTION}

Thorough analysis can be applied to various dimensions of a research paper and its strengths and weaknesses can be reviewed through intuitive critical appraisal. Research paper appraisal is conducted in the light of experience and by making comparisons with previous issues. In academic writing, critical appraisal is a methodological evaluation based on principles of analysis as well as through systematic and organized evaluation; it serves to increase the effectiveness and usefulness of a study (1). Critical appraisal can meet the study needs of individuals and the information can be beneficial in terms of familiarization with a new work. It also serves people inclined to know about a new range of specialized subjects. Significant practical application of a research paper is related to its critical review, which can broaden a reader's knowledge and highlight parts that may be overlooked (2). In recent years, an evolution in research studies has occurred and the number of qualitative research papers has increased. In this respect, critical appraisal studies on research papers needs to take steps to promote the quality of research papers; a process that is in itself useful (3-4).

The number of critical appraisals performed on qualitative research papers in Iran, particularly in the field of nursing, and its subgroups is quite limited. However, critical appraisal of published research papers is essential in order to improve their quality. Several research studies have been conducted in terms of critical appraisal of qualitative research papers $(2,5,6)$; however, research papers in nursing management are rare and there is a need for more critical appraisals of research papers, particularly for those in specialized subjects. Thus, the present study was done on critical appraisal of qualitative research papers published by Iranian scholars in the field of nursing management.

\section{MATERIAL AND METHOD}

In this cross-sectional study, a systematic search of the relevant literature was performed in the international databases of PubMed/MEDLINE, Scopus, CINAHL, Google Scholar, and the Persian electronic databases of Scientific Information Database (SID), Iran Medex, IranDoc, and Magiran. Searches applied the following keywords: qualitative studies, nursing management, and Iran in English or Persian up to December 2014. Qualitative research papers in the field of nursing management by Iranian authors, including those that had a corresponding author that was a nurse were included.

The Critical Appraisal Skills Program (CASP) checklist for qualitative research was used to review the papers. This checklist was a commonly used instrument for critical review of qualitative research studies (7). The CASP checklist for qualitative research had been developed in 10 main sections and 40 subsections. Through this appraisal checklist, the features including research purpose, methodological quality, research design and strategy, data collection method, methods of communication between researchers and participants, ethical principles in research, rigor of the study, and the valuable findings of a qualitative study were examined. The maximum score assigned to each research paper by this appraisal checklist was 43 , and each research paper obtained a certain score based on its content. Most appraisal studies used this instrument for a critical appraisal of a research paper with different approaches, including qualitative studies (8). Given the qualitative approach adopted in the research papers under review in the present study, this critical appraisal checklist was used to provide a review of the qualitative research studies (9). The CASP checklist was translated into Persian and then revised by an expert in English. This translated version was then confirmed by three different faculty members and then validated. A critical review of research papers was made from this appraisal checklist by three experts in developing qualitative research papers and each paper was given a score based on criteria in the checklist and by using the means of comments. Data were then analyzed by the SPSS software (version 16) using the paired t-test to assess relationships between indices for the research papers and the assigned scores. Spearman correlation coefficient was also used to examine relationships between the qualitative research papers.

\section{RESULTS}

The search strategy generated 1,954 articles. After initial screening and evaluation, 1,730 articles were rejected. Removing duplicates and application of a secondary screening resulted in selection of 22 articles for this study (Figure 1).

According to results, the majority of studies $(48 \%)$ were conducted using the methodology of grounded theory (Figure 2).

In terms of academic ranking, 4,815 authors were identified as full professor, associate professor, and assis- 
tant professor, respectively. Fifteen authors were doctorral candidates. The first research paper in the field of nursing management had been published internationally in 2008. Four papers had derived from doctoral dissertations in nursing. In terms of number of research papers per year, 2 and 5 studies were published in 2006 and 2009, respectively. Seven research papers were also published in 2012 and eight studies were published in 2013.

Following critical appraisal of qualitative studies and according to the subsections of the CASP checklist, these results were obtained (Table 1).

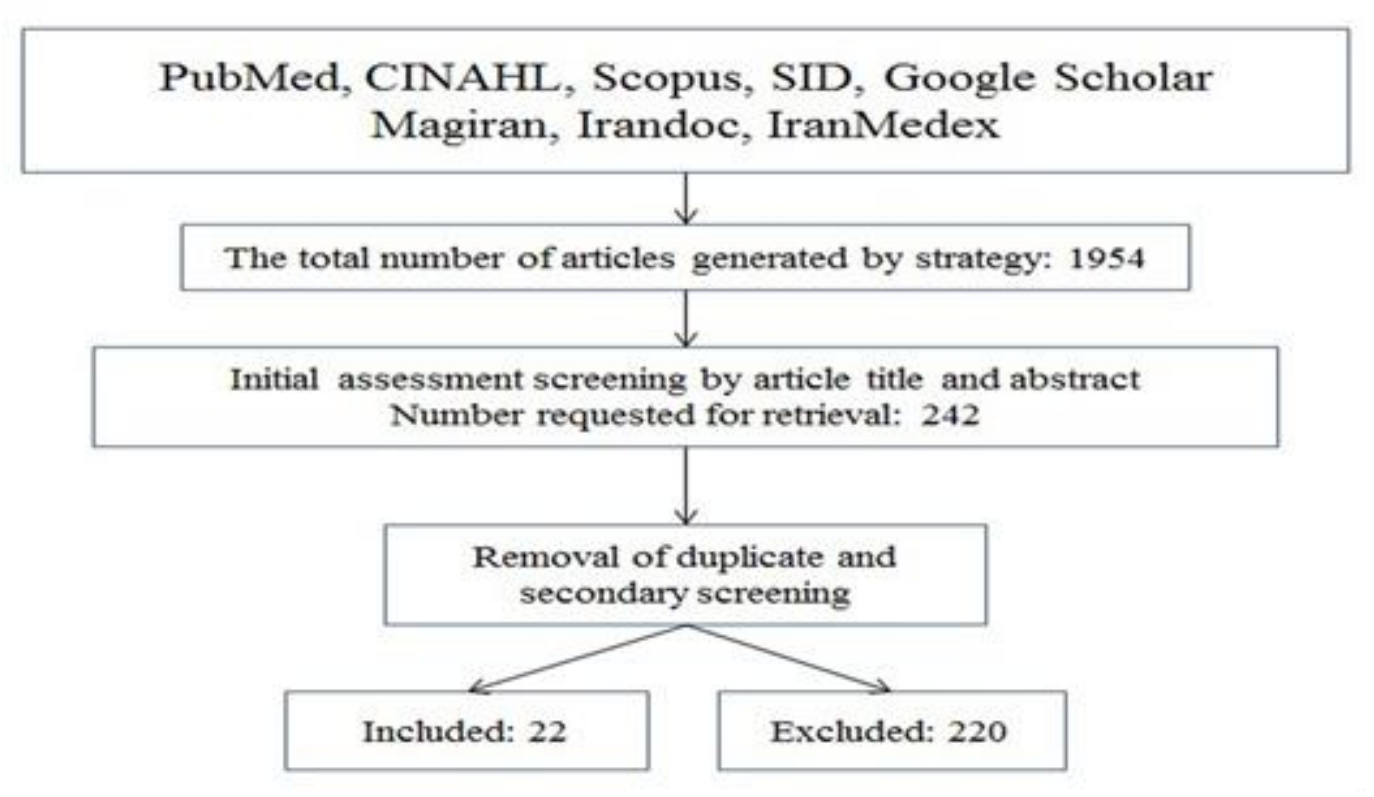

Figure 1: Literature search and retrieval flow diagram

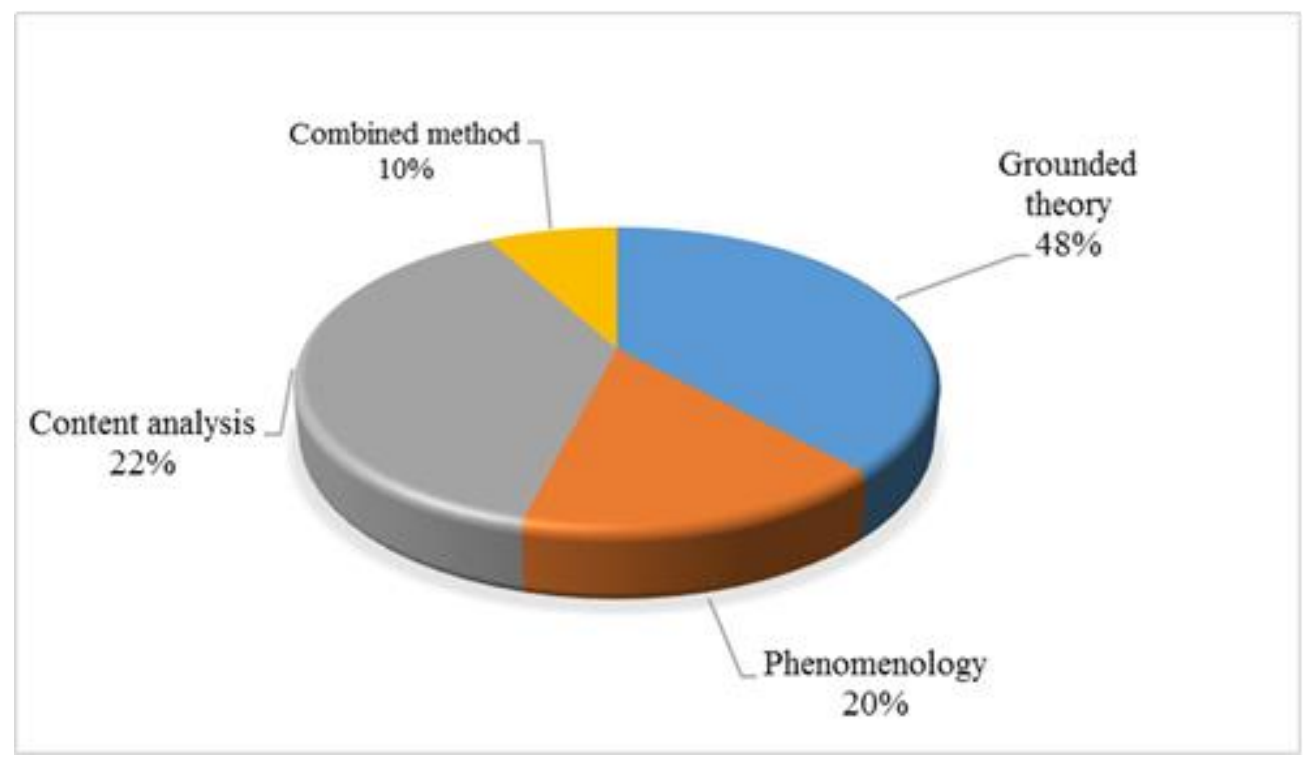

Figure 2: Percentages of use of different methods in qualitative research papers appraised in the study 
Table 1: Mean scores for research papers under review based on the criteria of the CASP for qualitative research

\begin{tabular}{l|c|c}
\hline \multicolumn{1}{c|}{ Factors evaluated in the research papers } & Scores & $\begin{array}{c}\text { Maximum } \\
\text { scores }\end{array}$ \\
\hline Clear statement of the aims of the research & 3.33 & 4 \\
\hline Quality of research method & 2.22 & 3 \\
\hline Research design and strategy & 2.77 & 6 \\
\hline Data collection & 4.44 & 7 \\
\hline Methods of communication between researchers and participants & 2.33 & 3 \\
\hline Ethical principles & 1.66 & 4 \\
\hline Rigor of the study & 5.123 & 9 \\
\hline Qualitative research findings & 2.44 & 4 \\
\hline Research value & 1.77 & 3 \\
\hline Total & $\mathbf{2 6 . 0 9}$ & $\mathbf{4 3}$ \\
\hline \hline
\end{tabular}

\section{Research purpose}

The purpose of the study is interrelated to the research question. Given the lack of research question in some papers, judgment on research objectives were not true; however, the purpose of the study and the research question were consistent in those qualitative research papers in which the research questions had been expressed explicitly. The score obtained in this area was 3.33 out of 4 .

\section{Literature review}

In the section of review of the related literature, the area of study in each research paper was highlighted and the studies in this section were linked to the main study. Some studies were not rich in terms of delineating any existing gap in the relevant field; in other words, the section for review of the related literature in such studies was considered unhelpful for understanding the author's purpose in writing the research paper.

\section{Study design}

In terms of frequency, design of the research papers included grounded theory, content analysis, phenomenology, and mixed-methods. A lack of rich description of details of the study made judgment about research methods and suitability of methods challenging for reviewers. In terms of value of the research papers, titles and contents of the studies revealed that titles selected the authors' expertise, also the subjects of nursing management were inter-related and titles were chosen based on authors' experiences as well as current issues in nursing. Another important point in these qualitative studies was the issue of challenges and problems in nursing. In this respect, no significant writing style was evident in the research papers published. Interviews were also the most common method of data collection in these research papers.

\section{Rigor of the study}

The conditions and the context of the study as important criteria for interpreting qualitative studies were not described in the contents. It should be noted that rigor was determined through the four criteria of credibility, dependability, transferability, and conformability. In addition, the most basic points under examination were data collection method, sampling method, and selection of qualified individuals to collect the data. In terms of rich description of data and increased rigor, diaries and notes at the time of the interviews had been used in these research papers that were clearly explained in the contents of a study. The score obtained in this respect was 2.77 out of 6 . In the research papers reviewed, the following cases related to this criterion were highlighted:

\section{A) Data collection and analysis}

The process of analysis in the studies under review did not follow the steps taken in qualitative data analysis. Only 4 papers referred to predictive validity in their data interpretation section. Considering data collection, the most common method was interview and other data collection methods including observation were neglected in these qualitative studies. The objectives of some studies were not clarified by the authors. The studies scored 4.44 out of 7 in this respect. 


\section{B) Sampling method}

Sampling method in the included studies was not well-defined; in some studies, some participants were excluded without explanation. Moreover, reasons behind selection or exclusion of participants had not been mentioned in some studies. In conclusion, the reviewed papers in the present study scored 4.44 out of 7 .

\section{C) Selection of qualified participants for data collection}

In terms of this criterion, there was required accuracy in the research papers examined; in fact, reasons behind selection of sample participants were specified.

\section{D) Ethical principles}

In the evaluated studies, only one study focused on ethical principles. The method of observation used for this important issue was neglected in other research papers.

\section{DISCUSSION}

In these qualitative research studies, the researchers used grounded theory on the basis of their own subjective assumptions or their research questions (48\%). The expertise of the researcher was an important and basic factor in this respect. This issue has not been considered in existing appraisal checklists and there is a hope that this criterion will be included in such instruments in the future $(10,11)$. In the present study, the research papers under review were examined and discussed according to considerations of important criteria for critical appraisal of a qualitative research paper; these were as follows: important dimensions of the research purpose, quality of the research method, research design and strategy, data collection and methods of communication between researchers and participants. In terms of purpose of the study, which was associated with the research question and considering a lack of raising questions in some research papers, judgment about the purpose of the study was wrong, but in papers that had an explicit explanation of the research question there was consistency between purpose and the research question. In the research papers reviewed, there was no sufficient documentation associated with opinions of participants; in addition, the conditions and context of the study, which important criteria in terms of interpreting qualitative research papers, were not explained in the contents of the qualitative research papers selected. It should be noted that in qualitative research studies, readers like the researchers, should relate personally to the event or phenomenon under investigation. This requires a rich description of the most important elements related to the study data i.e. information on the participants in a research. A clear description of details and rich interpretation in a qualitative research paper is in line with clarification of the research findings such that the reader relates to an event personally (12). The review of these research papers revealed that in most studies, the paper's contents (descriptions and interviews) did not provide readers with the same understandings as the researchers. An important criterion for qualitative studies is that researchers classify and explain the contents in such a way that a reader has the same understanding as the researchers when the contents are read. Most of the research papers lacked necessary descriptive information and full clarification in terms of analytic-interpretive descryptions. Moreover, researchers had not clearly focused on any measures taken, if there was a need for interpreting method of data collection in specific conditions or if the interview needed modification of its method. Considering the methods of communication between researchers and readers, a lack of rich description, researchers' reluctance in expressing their opinions, and potential changes during the research study related to participants and researchers' reactions in these conditions were not predicted. Clear explanations of the method of participant selection and reason for collaboration or withdrawal were not highlighted. In an appraisal of qualitative research papers, it was stated that the purpose of administering interviews was to elicit participants' real-life experiences and feelings. In this respect, semi-structured questions were the best choice, so participant selection was an important aspect of the research method. Therefore, reasons for selection or exclusion of participants in qualitative research papers needs to be clarified (13). It was assumed that the lack of clarification for the contents of qualitative research papers was due misuse of language; in other words, researchers did not express their findings in an intelligible manner (14).

In terms of quality of research method, a study by Thurston on consistency of research methods in complex research studies and their common concepts stated one of the most significant aspects in terms of validity of a paper, and that was maintenance of congruence of a research method $(13,14)$. In all the research papers in the present study, there was sufficient and direct consistency between findings and qualitative data. However, the 
most important point to mention is that discussions on findings were unsatisfactory. One of the threats to qualitative research papers in terms of rigor was clear expression of participants' opinions. In an investigation on the appraisal of qualitative research papers using metaanalysis, Arino et al. studied qualitative research papers in obstetrics in terms of quality and quantity. The critical appraisal determined that the methodology and epistemology of the research papers was described vaguely (15). Rachel et al. believed that the task of a researcher was to express the opinions, experiences, and behaviors of participants in a clear and detailed manner (16). For example, in one of the research papers, the researchers noted that "a group of nurses with a minimum 5-year working experience was included in this study" and the researchers provided comprehensive information in line with the research method. In another study, it was mentioned that "participants with 10-year working experience were selected".

In terms of the rigor and popularity of qualitative research papers, 5 papers discussed these issues considering research hypotheses and elements of the study. Among the research papers under review, 2 papers mentioned methods of observing ethical principles. In other research papers, this important issue was neglected while providing a form of ethical principles and an explicit focus on this issue was considered important in qualitative research papers. Ethical issues are considered to emerge at each step of the process of a qualitative research paper; thus, it was necessary to ensure confidentiality of data provided by participants and to obtain written consent during interviews. Issues such as revealing secrets and evidence of unethical or illegal activities were likely issues in this respect. Thus, qualitative research papers require compliance with personal values and appropriate ethical orientation (17).

According to Lewisand et al., qualitative research papers were mental and narrative analyses at the risk of criticism and were prone to researcher bias (conscious or inadvertent). Mixed-method studies apply a research method that increases internal consistency by using more than one method of data collection to address the research question and validate the research paper through analysis of the research question from multiple dimensions. This serves to improve agreement between researchers and participants as well as validation of the findings (18). Accuracy of analysis was subject to change by which researchers turn real data into abstract data through their knowledge, and this important criterion was hard to examine in most qualitative research papers (19). Critical appraisal of this criterion is not easy to apply and cases such as vague inclusion and exclusion criteria for the themes in the study, as well as provision of a table for classification and categorization of the themes with basic roles in making sense of researchers' opinions, have been mentioned as important in this respect. A theoretical relationship requires that theoretical design is developed including obvious expression, suitable logic, data reflection, and compatibility of output with nursing knowledge $(10,20)$. What was noteworthy in these research papers was that concepts needed to be validated through data obtained in the study, while some parts of research papers had provided documented data. In fact, this threat was visible in many qualitative research papers. In some of the studies, there was no evidence of context or concept mapping applied to data analysis. In the majority of these qualitative research papers, there was no marked theoretical relationship with the contents of nursing knowledge, particularly nursing practice, and readers were not able to establish a connection between a paper and nursing knowledge. The term nursing was an integral part of these research papers; however, it was essential to link the contents, particularly the findings, to the body of nursing knowledge as one of the basics of theoretical connection, according to Pluye et al. (21). In this respect, researchers were required to provide documents and evidence of an objective connection, and to deal with the limitations of the study (20). In terms of the method of communication between researchers and participants, there were not sufficient documents in the reviewed research papers, although the issue of free variation was highlighted. The role of the researcher was specified, data collection including sample selection and changes during the research to deal with the problems were also predicted to support the method of communication between researcher and participants. Ethical principles in qualitative research studies are based on trust and respect between researchers and research subjects. Ethical aspects of qualitative research include topic selection, description of research method, analysis of results, and provision of suggestions and criticisms (10). In all research papers and qualitative research papers in particular, ethical principles need to be observed or mentioned in the contents because interpretation is an indispensable part of the nature of a qualitative research paper (21). Moreover, access to rich information requires that participants express a personal account and speak freely $(22,23)$.

\section{CONCLUSION}

The critical appraisal of the research papers inclu- 
ded in this study revealed that qualitative research papers in nursing management were of lower quality than expected. The most important problem identified in these papers was compliance with the ethical principles of qualitative research studies. Given the development of the Declaration of Helsinki over recent decades, the ethical principles were neglected in the reviewed research papers. Therefore, consideration of ethical principles is recommended for inclusion in qualitative research studies. It is also essential that the most important aspects of qualitative research papers are mentioned and included in consent forms.

\section{Acknowledgement}

We hereby appreciate the respected authorities of the university libraries, honorable officials of information technology and human resources departments in the Faculty, and all the individuals who collaborated with this study.

\section{References}

1. Singh J. Critical appraisal skills programme. J Pharmacol Pharmacother 2013; 4(1):76.

2. Jones R, Green E, Hull C, Niesner E, Schofield P. Making an impact: research, publications, and bibliometrics in the BJGP. Br J Gen Pract 2012; 62(596): 157-9.

https://doi.org/10.3399/bjgp12X630214

3. Rosen A, Stein L, McGorry P, Harvey C, Birchwood, M, Diamond R. Specialist community teams backed by years of quality research .B J Psych Bulletin 2013; 37(1):38.

4. Heydari A, Emami Zeydi A. Barriers to and Facilitators of Research Utilization among Iranian Nurses: a Literature Review. J Caring Sci 2014;3(4):265-75.

5. Gioia DA, Corley KG, Hamilton AL. Seeking qualitative rigor in inductive research notes on the Gioia methodology. Organ Res Methods 2013; 16(1):1531.

https://doi.org/10.1177/1094428112452151

6. Balazs CL, Morello FR. The three Rs: How community-based participatory research strengthens the rigor, relevance, and reach of science. Environ Justice 2013;6(1). 9-16. https://doi.org/10.1089/env.2012.0017

7. Truluck CA, Leggett T. Critical Appraisal of Health Professions Research. Radiol Technol 2016; 87(3). 355-8.

8. Rolfe G. Validity, trustworthiness and rigour: quality and the idea of qualitative research. J Adv Nurs 2006; 53(3):304-10. https://doi.org/10.1111/j.1365-2648.2006.03727.x

9. Sandelowski M. A matter of taste: evaluating the quality of qualitative research. Nurs Inq 2015;22(2):86-94. https://doi.org/10.1111/nin.12080 
10. Cesario S, Morin K, Santa-Donato A. Evaluating the level of evidence of qualitative research. J Obstet Gynecol Neonatal Nurs 2002;31(6):708-14. https://doi.org/10.1177/0884217502239216

11. Fossey E, Harvey C, McDermott F, Davidson L. Understanding and evaluating qualitative research. Aust N Z J Psychiatry 2002;36(6):717-32. https://doi.org/10.1046/j.1440-1614.2002.01100.x

12. Sandelowski M. Focus on research methodswhatever happened to qualitative description? Res Nurs Health 2000;23(4):334-40. https://doi.org/10.1002/1098240X(200008)23:4<334::AID-NUR9>3.0.CO;2-G

13. Walsh D, Downe S. Appraising the quality of qualitative research. Midwifery 2006;22(2):108-19 https://doi.org/10.1016/j.midw.2005.05.004

14. Arino A, Lebaron C, Milliken F. Publishing Qualitative Research in Academy of Management Discoveries. Acad manage discover 2016;2(2):109-13. https://doi.org/10.5465/amd.2016.0034

15. Shahriari M, Mohammadi E, Abbaszadeh A, Bahrami M. Nursing ethical values and definitions: A literature review. Iran J Nurs Midwifery Res 2013; 18(1): 1-8.

16. Rachel A, Kornhaber A, deJong E, McLean L. Rigorous, robust and systematic: Qualitative research and its contribution to burn care: An integrative review. Burns 2015;41(8):1619-26. https://doi.org/10.1016/j.burns.2015.04.007
17.Heyvaert M, Hannes K, Maes B, Onghena P. Critical appraisal of mixed methods studies, Mix Methods Res 2013;4(3). 228-50. https://doi.org/10.1177/1558689813479449

18. Lewis, S. Qualitative inquiry and research design Choosing among five approaches. Health Promot Pract 2015;4(2):33.

19.DeWitt L, Ploeg J. Critical appraisal of rigour in interpretive phenomenological nursing research. J Adv Nurs 2006;55(2): 215-29. https://doi.org/10.1111/j.1365-2648.2006.03898.x

20. Leung L. Validity, reliability, and generalizability in qualitative research. J Family Med Prim Care 2015;4(3):324.

https://doi.org/10.4103/2249-4863.161306

21. Pluye P. Critical appraisal tools for assessing the methodological quality of qualitative, quantitative and mixed methods studies included in systematic mixed studies reviews. J Eval Clin Pract 2013; 19(4):722.

22. Brien O, Bridget C, Harris B I, Reed J, Darcy A, Cook D A. Standards for reporting qualitative research: a synthesis of recommendations. Acad Med 2014;89(9): 1245-51. https://doi.org/10.1097/ACM.0000000000000388

23. .Karimi Moonaghi H, Mirhaghi A, Oladi S, Emami Zeydi A. A journey across an unwelcoming field: A qualitative study exploring the factors influencing nursing students' clinical education. Health Sci J 2015;9(4): 1-6.. 


\title{
Kritička procena objavljenih kvalitativnih istraživanja na polju menadžmenta u sestrinstvu od strane iranskih autora: studija preseka
}

\author{
Abbas Heydari ${ }^{1}$, Seyed Majid Vafaei ${ }^{2}$, Mahmoud Bakhshi $^{3}$ \\ ${ }^{1}$ Centar za istraživanje nege zasnovane na dokazima, Departman za medicnsko-hirurško sestrinstvo, \\ Fakultet za sestrinstvo i akušerstvo, Univerzitet Medicinskih nauka Mashhad, Mashhad, Iran \\ ${ }^{2}$ Student doktorskih studija, Fakultet za sestrinstvo i akušerstvo, Univerzitet Medicinskih nauka Mashhad, \\ Mashhad, Iran \\ ${ }^{3}$ Centar za istraživanje nege zasnovane na dokazima, Departman za hirurgiju i anesteziju, Fakultet za sestrinstvo $i$ \\ akušerstvo, Univerzitet Medicinskih nauka Mashhad, Mashhad, Iran
}

\section{SAŽETAK}

Veliki broj doktoranata iz oblasti menadžmenta u sestrinstvu, sa fokusom na kvalitativne studije, doprineo je razvoju kvalitativnih studija. Cilj ove studije bio je da napravi kritičku procenu kvalitativnih istraživanja u polju menadžmenta u sestrinstvu od strane iranskih autora, koja su objavljena u domaćim i međunarodnim časopisima.

U studiji preseka korišćene su međunarodne i persijske elektronske baze zbog sistematske pretrage relevantne literature, pri čemu su tražene sledeće ključne reči: kvalitativne studije, menadžment u sestrinstvu, i Iran. Za kvalitativnu procenu uključenih studija korišćeni su kriterijumi ustanovljeni Programom za kritičku procenu veština (CASP-eng.).

Od 22 procenjene studije, $u$ 48\% je korišćena utemeljena teorija, dok je u $22 \%$ slučaja korišćen metod analize sadržaja. Prosečan skor kod etičkih razmatranja iznosio je 1,66 od 4. Prosečne vrednosti za ispitivanje rigoroznosti i verodostojnosti istraživanja iznosile su 5,123 od 9 i 1,66 od 4 . U pogledu cilja i metodologije, prosečne vrednosti su iznosile 3,33 od 4 i 2,22 od 3. Prosečna vrednost za kvalitet dizajna istraživanja je iznosio 2,66 od 6, a vrednost za metodu prikupljanja podataka je iznosila 4,44 od 7.

Rezultati su pokazali da kvalitet objavljenih kvalitativnih studija u polju menadžmenta u sestrinstvu nije zadovoljavajući i najveća slabost se odnosi na delimično usaglašavanje sa etičkim principima.

Ključne reči: kritička procena, kvalitativna istraživanja, menadžment u sestrinstvu, Iran 
Original article 